\title{
Frequency of Manure Application in Organic versus Annual Application of Synthetic Fertilizer in Conventional Vegetable Production
}

\author{
Vincent M. Russo' \\ U.S. Department of Agriculture, Agricultural Research Service, Wes Watkins \\ Agricultural Research Laboratory, 911 Highway 3W, Lane, OK 74555
}

Merritt Taylor

Oklahoma State University, Wes Watkins Agricultural Research and Extension Center, P.O. Box 128, Lane, OK 74555

Additional index words. bell pepper, conventional, cucumber, economics, fertilizer, manure, organic, sweet corn

\begin{abstract}
The cost of transporting manure can affect profit. Manure was applied either annually or biennially to bell pepper (Capsicum annuum L.), cv. Jupiter, cucumber (Cucumis sativus L.), cv. Earli Pik, and sweet corn (Zea mays var. rugosa Bonaf.), cv. Incredible (se endosperm genotype), produced using organic methods and compared with production of these crops using conventional methods and annually applied synthetic fertilizer. Conventional and organically maintained portions of the field were separated by a $25-\mathrm{m}$ buffer zone planted with sweet corn, which was provided with manure. The experiment was conducted from 2005 to 2008 at Lane, OK. Nutrient contents of soil and edible portions were determined as were yields. Economic analyses comparing costs of production and profit were conducted. There were yield responses resulting from year. Bell pepper yield was little affected by type of fertilizer application. Cucumber and sweet corn benefited from use of manure over conventional fertilizer. There was no pattern of alternating increased or decreased nutrient content in edible portions or in the soil as a result of annual or biennial application of manure. Treatment with manure produced higher returns than did conventional fertilizer. Annual treatment with manure produced higher returns in bell pepper and sweet corn than did treatment with manure in alternate years; the opposite was true for cucumber. Annual application of manure appears to be necessary for most of the vegetable crops tested.
\end{abstract}

In the United States through 2001, organic production was the fastest growing agricultural sector (Dimitri and Greene, 2002), and it has continued to expand (Organic Trade Association, 2007). In the southern plains of the United States, as a result of changes in demographics and economics, there is interest in converting land to crops that are not traditional to the region. One such use is vegetable production and would entail changing from row

\footnotetext{
Received for publication 2 Aug. 2010. Accepted for publication 2 Sept. 2010.

Mention of a trademark, vendor, or proprietary product does not constitute a guarantee or warranty of the product by the USDA and does not imply its approval to the exclusion of other products that may also be suitable. A USDA employee prepared the article as part of his official duties. Copyright protection under U.S. copyright law is not available for such works, and there is no copyright to transfer. The fact that the private publication in which the article appears is itself copyrighted does not affect the material that is a work product of the U.S. Government, which can be freely reproduced by the public.

${ }^{1}$ To whom reprint requests should be addressed; e-mailvrusso-usda@lane-ag.org.
}

crops or cow-calf operations. In the latter case, the transition would be from perennial pasture.

Organic production is used to improve the soil condition over the long term (Arden-Clarke and Hodges, 1988; Asami et al., 2003; Dabbert and Madden, 1986; Merrill, 1983; Smolik and Dobbs, 1991; Woese et al., 1997). Soil is amended with materials from organic sources, and if not available on-farm, they must be transported to the site and can impart additional cost in production of organic vegetables (Stanhill, 1990). Use of materials from organic sources may be more easily adaptable where animals are involved on-site in recycling of vegetable matter to the soil. According to the National Organic Program (NOP), animal manure can be used in the raw form with restrictions [U.S. Department of Agriculture, Agricultural Marketing Service (USDA, AMS), 2004, and amendments] or as aged compost. The latter has been successfully used for vegetable production (Ozores-Hampton and Peach, 2002).

For organic production, the more handson approach may add to expense and may require a premium market price for produce to make it competitive. Sellen et al. (1995) reported that in the second and third years of the transition to organic vegetable production, yields and economics of crops under study were less than for conventionally produced crops. Russo and Taylor (2006) determined that although yields were generally increasing for vegetables during the 3-year transition period, costs were higher than for conventionally grown vegetables.

Regardless of whether production is with conventional or alternative methods, it is necessary that systems be developed that are applicable to specific regions. Synthetic fertilizers cannot be used in organic production. There are several materials derived from organic sources that can be used in organic production, including those from plant and animal wastes (USDA, AMS, 2004, and amendments). Manures provide nutrients over time, increase rhizosphere microbial populations, and improve soil tilth (Lalande et al., 2005; Nardi et al., 2004). Chicken litter can increase phosphorus in the soil, which can be detrimental to plant development (Roberts et al., 2004; Verma et al., 2005). The objective of this study was to determine if annual or biennial amendment of soil with chicken litter, versus annual application of conventional fertilizer, affects yield, nutrient content of the soil and edible yield, and economics of production.

\section{Materials and Methods}

Site description and preliminary activities. The experiment was conducted on a Bernow (fine-loamy, silliceous, thermic, Glossic Paleudalf) soil at Lane, OK. Before this study the land was in the 3-year transition to organic production of vegetables (Russo and Taylor, 2006) and meets NOP (USDA, AMS, 2004, and amendments) requirements but has not been certified.

In the fall of 2004, the plant residue from bell pepper (Capsicum annuum L.), cucumber (Cucumis sativus L.), and sweet corn (Zea mays var. rugosa Bonaf.) was mowed, left for 2 weeks, and soil-incorporated. The entire area was disked and seeded with wheat (Triticum aestivum L.), a common cover crop for the region. In late Winter 2005, the wheat was mowed, left for 3 weeks and disked into the soil. Soil samples were taken across the entire field according to the methods of Johnson (1985) to determine residual rates of available nutrients. The 0.8 -ha field was divided into areas that would receive manure annually or biennially and organic management and the area receiving synthetic fertilizer annually and conventional management.

The area to receive manure was $\approx 0.5$ ha. The remainder of the field contained the area to be treated with conventional fertilizer and a barrier area between fertilizer treatments. Raised beds ( $20 \mathrm{~cm}$ high and $18-\mathrm{cm}$ wide bed tops) were formed from bare soil and oriented north to south on $0.9-\mathrm{m}$ centers across the entire field.

From the west there were six rows with the western-most two rows seeded to sweet corn before experimental plots were established. The next four rows were not planted and cultivated to maintain them weed-free. The barrier area contained 28 rows running north to south. The middle 16 of the 28 rows were planted with sweet corn. The remaining 
rows were not planted and kept weed-free by cultivation. The sweet corn in the barrier area was provided manure. Equipment used in both parts of the field was washed before moving between management types. Crops used were bell pepper, cv. Jupiter, processing cucumber, cv. Earli Pik, and sweet corn, cv. Incredible (se endosperm genotype).

Yearly activities - transplant production2005. Bell pepper was established as transplants produced in Styrofoam trays (Speedling; American Plant Products, Oklahoma City, OK) in a greenhouse using conventional or organic potting media and fertilizers. Transplant trays were $88 \times 34.5 \times 65 \mathrm{~cm}$ [length $(\mathrm{L}) \times$ width (W) $\times$ depth (D)] with 128 truncated pyramidal shaped cells, each of which was $3.5 \times 3.5 \times$ $60 \mathrm{~cm}(\mathrm{~L} \times \mathrm{W} \times \mathrm{D})$, with volumes of $36 \mathrm{~cm}^{3}$ (Russo, 2005).

In the second week of February in each year, trays were filled with Sunshine ${ }^{\circledR}$ potting mix [Sun Gro Horticulture, Bellevue, WA, Organic Materials Review Institute (OMRI), Eugene, OR, listed] or Reddi-Earth Plug and Seedling Mix ${ }^{\circledR}$ (Scotts-Sierra Horticultural Products, Marysville, $\mathrm{OH}$ ) the former for organic transplant production and the latter for transplants produced with conventional methods. Potting media were moistened and seed of bell pepper placed in cells. There are no organic equivalent seed for this superior cultivar. Untreated seed was obtained for use in the experiments. Media were kept moist with an overhead irrigation system. Two weeks after planting, when $90 \%+$ of seedlings had emerged, plants were thinned to one per cell; fertilizer applications were begun and continued weekly until seedlings were transplanted to the field. Organic transplants were fertilized with Neptune's Harvest, 2-3-1 NPK (Ocean Crest Seafoods, Gloucester, MA; OMRI-listed) liquid fertilizer applied at $16 \mathrm{~mL} \cdot \mathrm{L}^{-1}$. Conventional transplants were provided with a solution of a water-soluble synthetic fertilizer (Peters, 20-2020 NPK; Spectrum Group, St. Louis, MO) at 5 $\mathrm{g} \cdot \mathrm{L}^{-1}$ based on previous experience (Russo, 2005).

Field preparation-2005 manure application in organic production. This portion of the field was divided in to nine plots, three plots wide $\times$ three tiers deep, with rows oriented north to south. Each plot comprised $\approx 454 \mathrm{~m}^{2}$ and had 28 rows, each of which was $18 \mathrm{~m}$ in length, on $0.9-\mathrm{m}$ centers. To the north of each plot was a 2-m wide unplanted area, and to the east of each plot was a $1.8-\mathrm{m}$ wide unplanted area kept weed-free by cultivation. Chicken litter $\left(5 \mathrm{Mg} \cdot \mathrm{ha}^{-1}\right.$ ) was broadcastapplied in early February to the entire portion of the field under organic production and incorporated using a Liliston rolling cultivator (Bush Hog Corp., Selma, AL). Fertilizer recommendations for organic production are expressed differently than for conventional culture (McLaurin and Reeves, 2000) because nutrients in organic fertilizers are released more slowly than nutrients from salts (Taylor and Zenz, 1999). The extractable nutrient concentration of the manure is presented in Table 1.

Field preparation-2005 conventional production. This portion of the field was

Table 1. Average $\mathrm{pH}$, nutrients ${ }^{\mathrm{z}}$ on a dry basis, and electrical conductivity (EC) of chicken litter manure used in the organic portion of the plot before application in the first year.

\begin{tabular}{|c|c|c|c|c|c|c|c|c|c|c|c|c|c|}
\hline $\mathrm{pH}$ & $\mathrm{C}$ & $\mathrm{N}$ & $\mathrm{P}_{2} 0_{5}$ & $\mathrm{~K}$ & $\mathrm{Ca}$ & $\mathrm{Cu}$ & $\mathrm{Fe}$ & $\mathrm{Mg}$ & $\mathrm{Mn}$ & $\mathrm{Na}$ & $\mathrm{S}$ & $\mathrm{Zn}$ & $\mathrm{EC}$ \\
\hline 8.2 & 679.3 & 51.4 & 31.9 & 52.2 & 113.9 & 0.1 & 52.9 & 18.8 & 1.2 & 3.1 & 13.1 & 0.3 & 2487 \\
\hline
\end{tabular}

${ }^{\mathrm{z}}$ Carbon $(\mathrm{C})$, nitrogen $(\mathrm{N}), \mathrm{P}_{2} \mathrm{O}_{5}$, potassium $(\mathrm{K})$, calcium $(\mathrm{Ca})$, copper $(\mathrm{Cu})$, iron $(\mathrm{Fe})$, magnesium $(\mathrm{Mg})$, manganese (Mn), sodium (Na), sulfur (S), and zinc $(\mathrm{Zn})$ are in $\mathrm{kg} \cdot \mathrm{Mg}^{-1}$ and $\mathrm{EC}$ is in $\mu \mathrm{S}$; analysis performed by the Oklahoma State University Soil, Water \& Forage analytical Laboratory, Stillwater, OK.

divided into nine plots, three plots wide $\times$ three tiers deep, with rows oriented north to south. Plots in tiers were arranged so that they began and ended in line with those in the organic portion of the field. Plots consisted of three rows, which were $18 \mathrm{~m}$ in length, with a $2-\mathrm{m}$ unplanted area to the north of each plot and a 1.8-m unplanted area to the east of each plot and kept weed-free by disking. Plots were $\approx 50 \mathrm{~m}^{2}$. There were six rows to the east of treatment rows with the two eastern-most planted to sweet corn and the next four left unplanted and kept weed-free by cultivation. Synthetic fertilizer was applied as recommended based on the results of soil analysis (Motes and Roberts, 1994). The source of nitrogen $(\mathrm{N})$, phosphorus $(\mathrm{P})$, and potassium $(\mathrm{K})$ was ammonium nitrate, triple superphosphate, and muriate of potash, respectively. Amounts of nutrients brought levels in the soil to $\approx 75 \mathrm{~N}-112 \mathrm{P} 290 \mathrm{~K} \mathrm{~kg} \cdot \mathrm{ha}^{-1}$, which supported all crops used (Motes and Roberts, 1994). To the area to be planted with bell peppers and cucumbers, the herbicide trifluralin (Dow AgroSciences, St. Louis, MO) was preplantincorporated at recommended rates. The herbicide metolachlor (Ciba, Greensboro, NC) was preplant-incorporated to sweet corn at recommended rates.

Planting and crop maintenance activities2005. Crops under conventional and organic production were assigned to plots in a random manner. Crops were spatially arranged east to west in both portions of the field in the same sequence. Six-week-old bell pepper was transplanted on 19 Apr. 2005 with an in-row spacing of $46 \mathrm{~cm}$. Cucumber and sweet corn seed were sown on 30 Apr. 2005. Cucumbers were sown at a 46-cm in-row spacing and sweet corn sown at a $23-\mathrm{cm}$ in-row spacing. There are no organic equivalents of seed for these superior cultivars so untreated seed were used.

Crops in both portions of the field were regularly scouted. There was no need to apply pesticides to control insects or diseases in bell pepper. Cucumber seed were sown so that plants emerged and developed to avoid the time of year of greatest activity of Striped [Acalymma vittatum (Fabricius)] or Spotted Cucumber Beetle (Diabrotica undecimpuntata howardi Barber). The insecticide Bacillus thuringiensis was applied to sweet corn in the portion of the field receiving manure beginning at emergence of first silk and continuing at 3to 4-d intervals until silks desiccated. The insecticide Permethrin ${ }^{\circledR}$ (Helena Chemical, Collierville, TN) at $140 \mathrm{~g} \cdot \mathrm{ha}^{-1}$ was applied to sweet corn in the portion of the field under conventional production at first emergence of silk and then every 3 to $4 \mathrm{~d}$ until silks desiccated.

Yearly activities - 2006. The process described for organically and conventionally managed sections of the field was repeated with the following adjustments. Crops were spatially rotated within sections of the field: cucumber was planted where bell pepper was previously, sweet corn was planted where cucumber was previously, and bell pepper was planted where sweet corn was previously. In the portion of the field receiving manure, blocks were divided in half on a north-south axis. In half of each block manure was applied in mid-February at the same rate as in the first year. The other half of the block did not receive manure. The conventionally treated plots were established and maintained as before with the same type of spatial rotation as in the portion of the field managed organically. Bell peppers were transplanted on 19 Apr. 2006 and cucumber and sweet corn were planted on 19 May 2006. The plant residue remaining after the last harvest was mowed and incorporated. Wheat was established as a winter cover.

Activities-2007 and 2008. Plots were prepared in the same manner. In 2007, all plots were treated with manure in early February; in 2008, the half of the plots not receiving manure in 2006 again did not receive manure. The other half of plots received manure in early February. The plots receiving conventional fertilizer received it in 2007 and 2008. In both years, plants were rotated in blocks as described previously. In 2007, bell peppers were transplanted on 19 Apr. and cucumber and sweet corn planted on 17 May. In 2008, bell peppers were transplanted on 16 Apr. and cucumber and sweet corn planted on $28 \mathrm{Apr}$.

Activities common to all treatments. Overhead irrigation supplied the equivalent of $5 \mathrm{~cm}$ of water per week when there was insufficient precipitation. Yield data were obtained from all plants in the middle rows of plots. Total and marketable numbers of bell peppers, cucumber fruit, and sweet corn ears (with husks) were determined with marketable quality based on USDA standards (USDA, AMS, 1958, 1989, 1992). After the last harvest, plant debris was mowed. After 3 weeks, the debris was tilled under and soil samples from each fertilizer treatment and each crop were obtained as described previously. Nutrient content of edible portions of crops and soil from each block were determined using the methods described in Russo and Perkins-Veazie (2010). Untreated wheat seed was sown as a winter cover.

Data analysis. The experiment was arranged in a completely random design with treatment being fertilizer used [conventional (annual application) versus organic (annual or biennial application)]. Crops, and their subsequent rotations, were randomly arranged within fertilizer treatments with three replications. Data were accumulated and compared over years. Data were subjected to analysis of 
variance in SAS (Version 9.1; SAS, Inc., Cary, $\mathrm{NC})$. If interactions were present, they were analyzed with least squares means analysis and used to explain results. If interactions were not significant, means were separated using the Ryan-Einot-Gabriel-Welsch multiple range test in SAS.

Economic analyses. Costs of production were determined by combining actual costs and converting them to 1-ha estimates for normalization and comparison purposes. Chemical costs were calculated by multiplying actual amounts of inputs applied by cost of those products during the year of application. Labor was estimated at $\$ 10 / \mathrm{h}$. Equipment use was calculated using average custom rates for specific operations. Prices used for yields were from the Dallas terminal market on the day of harvest (USDA, AMS, 2005-2008). Revenue per hectare minus total cost per hectare produced net revenue per hectare. To obtain total net revenue for all crops, it was assumed that there were 3 ha, one for each crop, over the period. Net revenues do not include costs of transportation from the field to the Dallas terminal market and are overestimates of potential net revenue. No premium was assigned to crops that could be designated as being produced organically.

\section{Results}

Weather. Rainfall and temperature patterns in 2005 and 2006 were similar to rainfall and temperature patterns in 2007 and 2008 but different from those in 2005 and 2006 (Fig. 1).
Temperatures were lower earlier in 2005 2006 than in 2007-2008. Precipitation occurred more frequently in 2005-2006 but at lesser amounts than in 2007-2008.

Yield. The crops responded differently to treatment (Table 2). For bell pepper, year affected all yield components except marketable number of fruit and marketable yield; fertilizer treatment affected average marketable fruit weight, and the year $\times$ fertilizer treatment interaction affected average cull yield and average cull fruit weight. For cucumber, year affected all yield components. Fertilizer treatment did not affect cull number and average weight of cull fruit. The interaction was not significant for number of marketable fruit. For sweet corn, year affected all yield components except average marketable ear weight; fertilizer treatment affected only marketable number of ears and marketable yield; yield components were unaffected by the interaction.

For bell pepper, average marketable numbers of fruit and marketable yield were 75,015 and $10.1 \mathrm{Mg} \cdot \mathrm{ha}^{-1}$, respectively. The greatest average marketable fruit weight $(154.4 \mathrm{~g})$ was in 2007; plants receiving manure produced heavier marketable fruit (average $138.5 \mathrm{~g}$ ) than plants receiving conventional fertilizer $(127.1 \mathrm{~g})$. More cull fruit were produced in 2005 and 2006 (average 27,956/ha) than in 2007-2008 (11,547/ha). There were no differences in cull fruit number as a result of treatment $(17,251 / \mathrm{ha})$. In 2006, the bell pepper cull fruit yield was highest in conventionally grown plants and those receiving manure annually $\left(2.6 \mathrm{mt} \cdot \mathrm{ha}^{-1}\right)$. In 2008 , yield was lowest in conventionally grown plants $(0.2$ $\left.\mathrm{mt} \cdot \mathrm{ha}^{-1}\right)$. Average cull fruit weight was greatest in 2007 for plants grown conventionally (334.4 g).

For cucumber, the most marketable fruit were produced in 2005 (101,019/ha) and $2008(111,225 / \mathrm{ha}) ; \approx 67,772 /$ ha were produced in 2006 and only 17,979/ha in 2007 . Application of manure produced plants with numbers of fruit that were similar $(85,756 /$ ha), and greater, than for plants provided conventional fertilizer $(57,985 / \mathrm{ha})$. In most years, marketable cucumber yield was similar for plants receiving manure; conventionally fertilized plants generally had lower yields (Table 3). Exceptions were in 2006 when plants receiving manure biennially had lower yields than plants receiving manure annually; in 2007, yields of conventionally fertilized plants had higher yields. Average marketable fruit weight was unaffected by treatment in 2005 and 2008. In 2006, average marketable fruit weight for plants receiving manure annually was greater than for plants receiving manure biennially; that value was not different from plants receiving conventional fertilizer. In 2007, plants receiving manure had similar fruit weight but were significantly lighter than that of plants receiving conventional fertilizer. Cull numbers of fruit were unaffected by treatment in 2005 and 2008. In 2006, plants receiving manure had similar numbers of cull fruit, which were higher than for plants receiving conventional fertilizer. In 2007, plants receiving manure
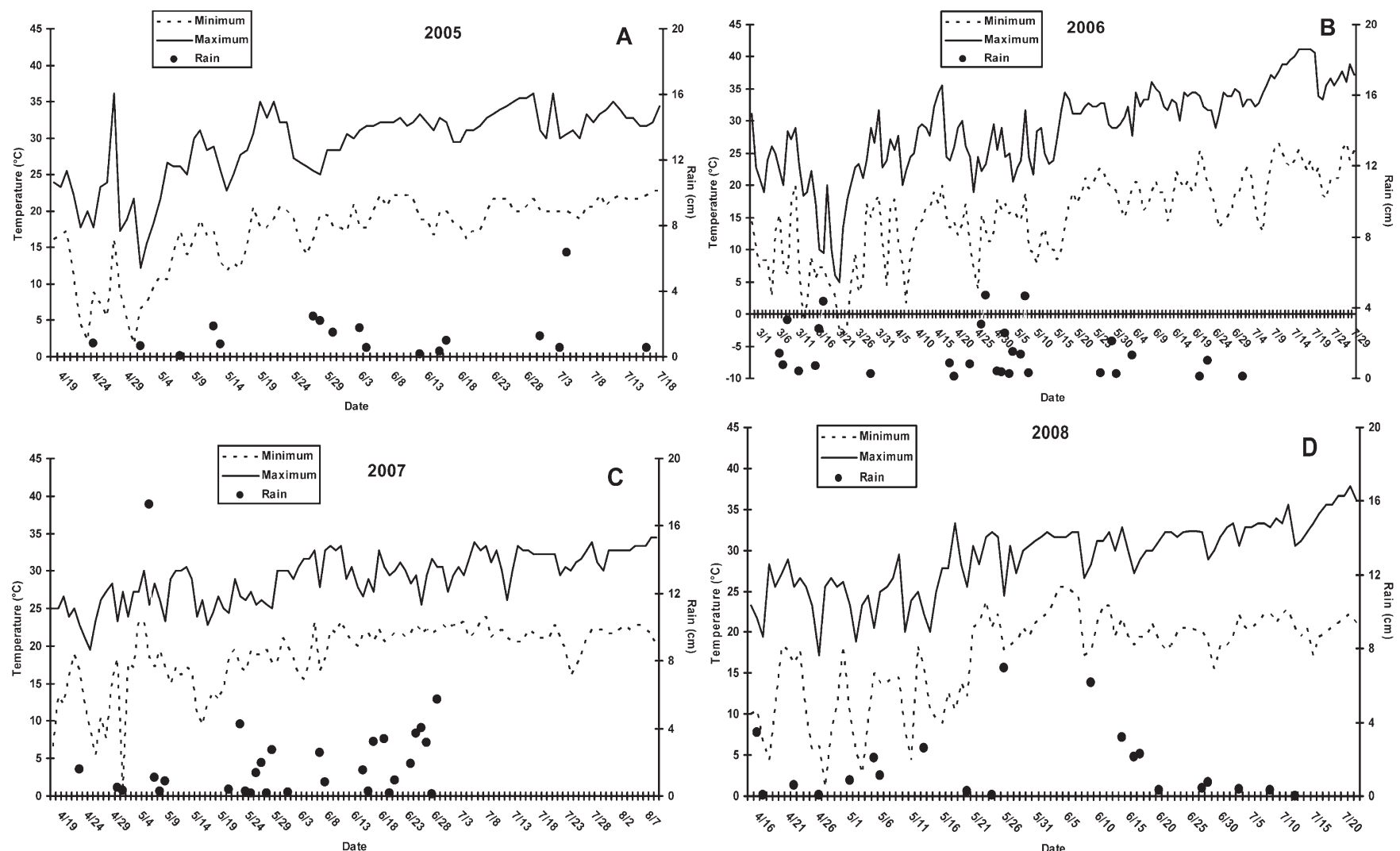

Fig. 1. Temperature and precipitation for the 2005 (A), 2006 (B), 2007 (C), and 2008 (D) growing seasons. 
Table 2. Analysis of variance table for effects of year and fertilizer application on yield components in vegetables.

\begin{tabular}{|c|c|c|c|c|c|c|}
\hline \multirow[b]{2}{*}{ Source } & \multicolumn{3}{|c|}{ Marketable } & \multicolumn{3}{|c|}{ Cull } \\
\hline & Number & Yield & $\begin{array}{c}\text { Edible portion } \\
\text { avg. wt }\end{array}$ & Number & Yield & $\begin{array}{c}\text { Edible portion } \\
\text { avg. wt }\end{array}$ \\
\hline & \multicolumn{6}{|c|}{ Bell pepper } \\
\hline Year $(Y)$ & NS & NS & $* *$ & $* *$ & $* *$ & $* *$ \\
\hline Fertilizer treatment $(\mathrm{F})$ & NS & NS & $* *$ & NS & NS & NS \\
\hline \multicolumn{7}{|l|}{ Interaction } \\
\hline \multirow[t]{2}{*}{$\mathrm{Y} \times \mathrm{F}$} & NS & NS & NS & NS & $*$ & $*$ \\
\hline & \multicolumn{6}{|c|}{ Cucumber } \\
\hline Year $(Y)$ & $* *$ & $* *$ & $* *$ & $* *$ & $* *$ & $* *$ \\
\hline Fertilizer treatment $(\mathrm{F})$ & $* *$ & $* *$ & $*$ & NS & $*$ & NS \\
\hline \multicolumn{7}{|l|}{ Interaction } \\
\hline \multirow[t]{2}{*}{$\mathrm{Y} \times \mathrm{F}$} & NS & ** & $* *$ & ** & $* *$ & $* *$ \\
\hline & \multicolumn{6}{|c|}{ Sweet corn } \\
\hline Year $(Y)$ & $* *$ & $* *$ & NS & $* *$ & $* *$ & ** \\
\hline Fertilizer treatment $(\mathrm{F})$ & $* *$ & $* *$ & NS & NS & NS & NS \\
\hline Interaction & & & & & & \\
\hline $\mathrm{Y} \times \mathrm{F}$ & NS & NS & NS & NS & NS & NS \\
\hline
\end{tabular}

Table 3. Effects of the year $\times$ fertilizer application interaction on yield components in cucumber.

\begin{tabular}{|c|c|c|c|c|c|c|}
\hline & & \multicolumn{2}{|c|}{ Marketable } & \multicolumn{3}{|c|}{ Cull } \\
\hline \multicolumn{2}{|c|}{ Source } & 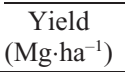 & $\begin{array}{c}\text { Fruit } \\
\text { avg. wt (g) }\end{array}$ & $\begin{array}{l}\text { Number } \\
\left(\mathrm{ha}^{-1}\right)\end{array}$ & 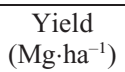 & $\begin{array}{c}\text { Fruit } \\
\text { avg. wt (g) }\end{array}$ \\
\hline \multicolumn{7}{|c|}{ Year $\times$ fertilizer treatment } \\
\hline \multirow[t]{3}{*}{2005} & Organic-manure annually & 15.0 & 149.8 & 23,365 & 1.6 & 72.6 \\
\hline & Organic_-manure biennially & $16.4 \mathrm{NS}$ & $136.2 \mathrm{NS}$ & $23,680 \mathrm{NS}$ & $1.3 \mathrm{NS}$ & $59.0 \mathrm{NS}$ \\
\hline & Conventional & $9.2 * *$ & $113.5 \mathrm{NS}$ & $16,983 \mathrm{NS}$ & $1.1 \mathrm{NS}$ & $68.1 \mathrm{NS}$ \\
\hline \multirow[t]{3}{*}{2006} & Organic_manure annually & 22.8 & 276.9 & 43,838 & 7.4 & 172.5 \\
\hline & Organic_manure biennially & $17.2 *$ & $204.3 *$ & $39,227 \mathrm{NS}$ & $4.3 * *$ & $113.5 \mathrm{NS}$ \\
\hline & Conventional & $10.1 * *$ & $267.9 \mathrm{NS}$ & $19,850 * *$ & $2.2 \mathrm{NS}$ & $109.0 \mathrm{NS}$ \\
\hline \multirow[t]{3}{*}{2007} & Organic-manure annually & 2.5 & 204.3 & 26,193 & 4.7 & 190.7 \\
\hline & Organic_manure biennially & $2.0 \mathrm{NS}$ & $168.0 \mathrm{NS}$ & $18,896 \mathrm{NS}$ & $3.1 \mathrm{NS}$ & $168.0 \mathrm{NS}$ \\
\hline & Conventional & $12.5 * *$ & $381.4 * *$ & $35,879 * *$ & $12.1 * *$ & $340.5^{* *}$ \\
\hline \multirow[t]{3}{*}{2008} & Organic-manure annually & 17.9 & 128.5 & 2,491 & 0.2 & 131.7 \\
\hline & Organic - manure biennially & $17.5 \mathrm{NS}$ & $125.8 \mathrm{NS}$ & $4,285 \mathrm{NS}$ & $0.4 \mathrm{NS}$ & $109.0 \mathrm{NS}$ \\
\hline & Conventional & $4.5 * *$ & $72.2 \mathrm{NS}$ & 996 NS & $0.2 \mathrm{NS}$ & $99.9 \mathrm{NS}$ \\
\hline
\end{tabular}

NS, *,** Non-significant or significant at $P \leq 0.05$ and $P \leq 0.01$, respectively, within year and fertilizer grouped comparisons, least squares means analysis. In this type of analysis, the second and subsequent means in each grouped comparison are compared with the value above it.

had similar numbers of cull fruit that were lower than plants receiving conventional fertilizer. In 2005 and 2008, cull fruit yield was unaffected by treatment. In 2006, cull fruit yield was highest for plants receiving manure annually; cull yield from plants receiving manure biennially, and those receiving conventional fertilizer, were similar. In 2007, cull fruit yield was similar for plants receiving manure and less for those receiving conventional fertilizer. Average cull fruit weight was unaffected by treatment, except in 2007 when plants receiving manure had similar, lower average fruit weights than plants receiving conventional fertilizer.

Year and fertilizer treatment affected production of marketable sweet corn ears (Table $4)$. The fewest number of marketable ears was produced in 2007. Most ears were from plants receiving manure annually. The highest marketable yield was produced in 2005 . Marketable yield for plants receiving manure was similar. Marketable yield of plants receiving manure biennially was similar to that receiving conventional fertilizer. Average marketable ear weight was $286 \mathrm{~g}$. Year affected cull ear production and weight. The greatest number of cull ears $(996 / \mathrm{ha})$ and greatest cull yield $\left(1.6 \mathrm{Mg} \cdot \mathrm{ha}^{-1}\right)$ was in 2006 ; the lowest average cull ear weight (63.6 g) was in 2007. The number of cull fruit, cull yield, and average cull ear weight resulting from fertilizer treatment were 2763 plants/ha, $0.5 \mathrm{Mg} \cdot \mathrm{ha}^{-1}$, and $99.9 \mathrm{~g}$, respectively.

Tissue content analysis. The analysis of variance (ANOVA) indicated little difference resulting from treatment on nutrient content in edible portions of crops (data not shown). The ANOVA determined that year generally affected nutrient content; exceptions were for bromine $(\mathrm{Br})$ and fluoride (Fl), which were consistently unaffected, and sodium $(\mathrm{Na})$ in cucumber peels, which was unaffected. Fertilizer treatment affected $\mathrm{K}$ levels in bell pepper fruit and $\mathrm{PO}_{4}$ level in cucumber peel. There was no year $\times$ treatment interaction affecting nutrient content. Contents of $\mathrm{Br}$ and Fl averaged 0.010 and $0.02 \mu \mathrm{g} \cdot \mathrm{g}^{-1}$ in bell pepper fruit; 0.049 and $0.015 \mu \mathrm{g} \cdot \mathrm{g}^{-1}$ in cucumber flesh; 0.019 and $0.01 \mu \mathrm{g} \cdot \mathrm{g}^{-1}$ in cucumber peel; and 0.00004 and $0.0 \mu \mathrm{g} \cdot \mathrm{g}^{-1}$ in sweet corn kernels, respectively. In cucumber peels, $\mathrm{Na}$ content
Table 4. Effects of year and fertilizer treatment on average marketable number and yield of ears in sweet corn.

\begin{tabular}{|c|c|c|}
\hline \multirow[b]{2}{*}{ Source } & \multicolumn{2}{|c|}{ Marketable ear } \\
\hline & Number/ha & 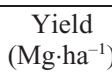 \\
\hline \multicolumn{3}{|l|}{$\overline{\text { Year }}$} \\
\hline 2005 & $32,130 \mathrm{a}^{\mathrm{z}}$ & $9.6 \mathrm{a}$ \\
\hline 2006 & $23,919 \mathrm{a}$ & $5.8 \mathrm{~b}$ \\
\hline 2007 & $12,479 \mathrm{~b}$ & $3.8 \mathrm{~b}$ \\
\hline 2008 & $23,786 \mathrm{a}$ & $7.2 \mathrm{~b}$ \\
\hline \multicolumn{3}{|l|}{ Fertilizer treatment } \\
\hline $\begin{array}{l}\text { Organic-manure } \\
\text { annually }\end{array}$ & $29,600 \mathrm{a}$ & $8.3 \mathrm{a}$ \\
\hline $\begin{array}{l}\text { Organic-manure } \\
\text { biennially }\end{array}$ & $21,678 \mathrm{~b}$ & $6.5 \mathrm{ab}$ \\
\hline Conventional & $11,959 \mathrm{~b}$ & $5.2 \mathrm{~b}$ \\
\hline
\end{tabular}

${ }^{\mathrm{z}}$ Values in a column followed by the same letter are not significantly different, $P \leq 0.05$, Ryan-EinotGabriel-Welsch multiple range test.

averaged $0.063 \mu \mathrm{g} \cdot \mathrm{g}^{-1}$. In bell pepper fruit, $\mathrm{K}$ content was affected by fertilizer treatment as was $\mathrm{PO}_{4}$ in cucumber peels. In bell pepper, $\mathrm{K}$ levels in fruit from plants receiving conventional fertilizer was $3.21 \mu \mathrm{g} \cdot \mathrm{g}^{-1}$, which was higher than for fruit from plants receiving manure, average $1.81 \mu \mathrm{g} \cdot \mathrm{g}^{-1}$. In cucumber peels, $\mathrm{PO}_{4}$ levels in fruit from plants receiving conventional fertilizer was $0.17 \mu \mathrm{g} \cdot \mathrm{g}^{-1}$, which was lower than for fruit from plants receiving manure, average $0.29 \mu \mathrm{g} \cdot \mathrm{g}^{-1}$.

Year affected nutrient content in edible portions of crops (Table 5). For bell pepper, fruit contents of $\mathrm{N}$ in a Kjeldahl digest (TKN), $\mathrm{PO}_{4}$, and magnesium were highest in 2008 and contents of $\mathrm{K}$, calcium $(\mathrm{Ca})$, and $\mathrm{Na}$ were highest in 2005. For P in a Kjeldahl digest (TKP), levels were higher, and similar, in 2007 and 2008; the value in 2007 was also similar to that in 2005; levels of nitratenitrogen and $\mathrm{SO}_{4}$ were highest, and similar, in 2005 and 2008. Levels of nitrite-nitrogen were highest in 2007 and 2008. Levels of chlorine $(\mathrm{Cl})$ were higher, and similar, in 2005 and 2008; the value in 2008 was similar to those in 2006 and 2007.

For cucumber flesh contents of $\mathrm{TKN}$, nitrite-nitrogen and magnesium $(\mathrm{Mg})$ were highest in 2008 and contents of $\mathrm{K}, \mathrm{Ca}, \mathrm{Cl}$, and $\mathrm{Na}$ were highest in 2005 . Levels of nitratenitrogen and $\mathrm{SO}_{4}$ were highest, and similar, in 2005 and 2008. Levels of TKP were highest in 2007. Levels of $\mathrm{PO}_{4}$ were highest, and similar, in 2005 and 2008; the level in 2005 was similar to that in 2007 and the 2007 level similar to that in 2006. For cucumber peels, contents of TKN, nitrite-nitrogen, $\mathrm{Mg}$, and $\mathrm{SO}_{4}$ were highest in 2008. Contents of $\mathrm{Cl}$ and $\mathrm{K}$ were highest in 2005. Levels of nitrate-nitrogen and $\mathrm{PO}_{4}$ were highest, and similar, in 2005 and 2008. Levels of TKP were highest in 2007. Levels of Ca were highest in 2005 and 2007.

For sweet corn kernels, TKN and $\mathrm{Mg}$ contents were highest in 2008; levels of nitrate-nitrogen, $\mathrm{K}, \mathrm{Ca}$, and $\mathrm{Na}$ were highest in 2005. The $\mathrm{SO}_{4}$ levels were highest, and similar, in 2005 and 2008. The TKP level was highest in 2006. Levels of $\mathrm{PO}_{4}$ were highest in 2005 and similar to that in 2007 ; the level 
in 2007 was similar to that in 2006. Levels of $\mathrm{Cl}$ were highest in 2005 and 2006, and similar to that in 2007, and the level in 2007 was similar to that in 2008.

Soil nutrient content analysis. The ANOVA indicated little difference resulting from treatments on residual nutrients in soil (data not shown). The ANOVA determined that year generally affected nutrient content; the exception was for $\mathrm{Br}$, which was consistently unaffected. Fertilizer treatment affected $\mathrm{Cl}$ levels in soil supporting cucumber and sweet corn. The $\mathrm{Br}$ content averaged: $1.29 \mu \mathrm{g} \cdot \mathrm{g}^{-1}$ in soil supporting bell pepper; $1.67 \mu \mathrm{g} \cdot \mathrm{g}^{-1}$ in soil supporting cucumber, and $1.54 \mu \mathrm{g}^{-1} \mathrm{~g}^{-1}$ in soil supporting sweet corn.

Year affected soil nutrient content (Table 6). For soil supporting bell pepper, TKP and $\mathrm{K}$ contents were highest in 2008; contents of $\mathrm{Ca}, \mathrm{Na}$, and $\mathrm{SO}_{4}$ were highest in 2005. For $\mathrm{PO}_{4}$ and $\mathrm{Cl}$, levels were highest in 2006 and
Mg highest in 2007. Levels of nitrate-nitrogen were among the highest, and similar, in 2005 and 2008, and the value in 2008 was similar to that in 2006. Nitrite-nitrogen levels were among the highest, and similar, in 2005 and 2008. Levels of Fl were highest in 2007 and 2008. Levels of TKN were among the highest and similar, in 2006 and 2008, and in 2006 similar to those in 2005 and 2007.

For soil supporting cucumber, contents of TKP and $\mathrm{K}$ were highest in 2008 and contents of $\mathrm{Na}$ and $\mathrm{SO}_{4}$ were highest in 2005. Levels of nitrate-nitrogen were highest and similar in 2005 and 2008; levels of $\mathrm{PO}_{4}$ were highest in 2006, $\mathrm{Cl}$ levels were highest in 2006, and levels of Mg were highest in 2007 and 2008. Levels of TKN were among the highest in 2006 and 2008; the value in 2006 was similar to that in 2007, and that value was similar to that from 2005. Levels of Fl were similar, and among the highest, in 2005 and 2008, and the
2008 value was similar to those in 2006 and 2007. The nitrate-nitrogen level in 2006 was among the highest and similar to those in 2005 and 2008, and the value in 2005 and 2008 was similar to that in 2007. The Fl levels from 2006 to 2008 were among the highest and the value from 2006 was similar to that from 2005.

For soil supporting sweet corn, TKP and $\mathrm{K}$ contents were highest in 2008 and those of $\mathrm{Ca}, \mathrm{Na}$, and $\mathrm{SO}_{4}$ were highest in 2005 . Nitrate - nitrogen was highest and similar in 2006 and 2008. Levels of $\mathrm{PO}_{4}$ and $\mathrm{Cl}$ were highest in 2006. Levels of Fl were highest in 2007 and 2008; levels of $\mathrm{Mg}$ were highest in 2007. Levels of TKN were among the highest and similar in 2006 and 2008; the value in 2006 was similar to that in 2005 and 2007.

Content of $\mathrm{Cl}$ was affected by fertilizer treatment in soil supporting cucumber and sweet corn. For cucumber, levels of $\mathrm{Cl}$ in soil treated

Table 5. Effect of year on nutrient content, values in $\mu \mathrm{g} \cdot \mathrm{g}^{-1}$, of edible portions of vegetables.

\begin{tabular}{|c|c|c|c|c|c|c|c|c|c|c|c|}
\hline \multirow[b]{2}{*}{ Year } & \multirow[b]{2}{*}{$\mathrm{TKN}^{\mathrm{z}}$} & \multicolumn{2}{|c|}{ Nitrogen } & \multirow[b]{2}{*}{$\mathrm{TKP}^{z}$} & \multirow[b]{2}{*}{$\mathrm{PO}_{4}$} & \multirow[b]{2}{*}{ Potassium } & \multirow[b]{2}{*}{ Calcium } & \multirow[b]{2}{*}{ Chlorine } & \multirow[b]{2}{*}{ Magnesium } & \multirow[b]{2}{*}{ Sodium } & \multirow[b]{2}{*}{$\mathrm{SO}_{4}$} \\
\hline & & Nitrate & Nitrite & & & & & & & & \\
\hline 2005 & $0.53 \mathrm{~b}^{\mathrm{y}}$ & $0.030 \mathrm{a}$ & $0.008 \mathrm{bc}$ & $0.13 \mathrm{~b}$ & $0.21 \mathrm{~b}$ & $8.74 \mathrm{a}$ & $0.23 \mathrm{a}$ & $0.45 \mathrm{a}$ & $0.13 \mathrm{~b}$ & $0.16 \mathrm{a}$ & $0.40 \mathrm{a}$ \\
\hline 2006 & $0.46 \mathrm{~b}$ & $0.002 \mathrm{~b}$ & $0.003 \mathrm{c}$ & $0.10 \mathrm{c}$ & $0.06 \mathrm{c}$ & $0.29 \mathrm{~b}$ & $0.05 \mathrm{~b}$ & $0.23 \mathrm{~b}$ & $0.03 \mathrm{~b}$ & $0.09 \mathrm{~b}$ & $0.10 \mathrm{~b}$ \\
\hline 2008 & $1.47 \mathrm{a}$ & $0.042 \mathrm{a}$ & $0.017 \mathrm{a}$ & $0.16 \mathrm{a}$ & $0.32 \mathrm{a}$ & $0.08 \mathrm{~b}$ & $0.01 \mathrm{~b}$ & $0.30 \mathrm{ab}$ & $1.90 \mathrm{a}$ & $0.04 \mathrm{~b}$ & $0.49 \mathrm{a}$ \\
\hline \multicolumn{12}{|c|}{ Cucumber-flesh } \\
\hline 2007 & $0.57 \mathrm{~b}$ & $0.001 \mathrm{~b}$ & $0.001 \mathrm{~b}$ & $0.28 \mathrm{a}$ & $0.13 b c$ & $1.87 \mathrm{~b}$ & $0.15 \mathrm{~b}$ & $0.43 \mathrm{~b}$ & $0.04 \mathrm{~b}$ & $0.04 \mathrm{c}$ & $0.01 \mathrm{~b}$ \\
\hline 2008 & $1.63 \mathrm{a}$ & $0.012 \mathrm{a}$ & $0.047 \mathrm{a}$ & $0.21 \mathrm{~b}$ & $0.53 \mathrm{a}$ & $0.08 \mathrm{~b}$ & $0.05 \mathrm{c}$ & $0.42 \mathrm{~b}$ & $1.76 \mathrm{a}$ & $0.10 \mathrm{~b}$ & $0.51 \mathrm{a}$ \\
\hline \multicolumn{12}{|c|}{ Cucumber-peel } \\
\hline 2005 & $0.55 \mathrm{~b}$ & $0.012 \mathrm{a}$ & $0.002 \mathrm{~b}$ & $0.17 \mathrm{c}$ & $0.31 \mathrm{a}$ & $16.07 \mathrm{a}$ & $0.20 \mathrm{a}$ & $1.49 \mathrm{a}$ & $0.39 \mathrm{~b}$ & $0.10 \mathrm{a}$ & $0.33 \mathrm{~b}$ \\
\hline 2006 & $0.56 \mathrm{~b}$ & $0.003 \mathrm{~b}$ & $0.004 \mathrm{~b}$ & $0.11 \mathrm{~d}$ & $0.13 \mathrm{~b}$ & $0.02 \mathrm{~b}$ & $0.12 \mathrm{~b}$ & $0.30 \mathrm{c}$ & $0.04 \mathrm{~b}$ & $0.03 \mathrm{a}$ & $0.06 \mathrm{c}$ \\
\hline 2007 & $0.54 \mathrm{~b}$ & $0.001 \mathrm{~b}$ & $0.000 \mathrm{~b}$ & $0.28 \mathrm{a}$ & $0.06 \mathrm{~b}$ & $1.88 \mathrm{~b}$ & $0.27 \mathrm{a}$ & $0.42 \mathrm{bc}$ & $0.04 \mathrm{~b}$ & $0.04 \mathrm{a}$ & $0.01 \mathrm{c}$ \\
\hline \multicolumn{12}{|c|}{ Sweet corn-kernel } \\
\hline 2007 & $0.53 \mathrm{~b}$ & $0.002 \mathrm{~b}$ & $0.005 \mathrm{~b}$ & $0.11 \mathrm{~b}$ & $0.24 \mathrm{ab}$ & $0.04 \mathrm{~b}$ & $0.03 \mathrm{~b}$ & $0.21 \mathrm{ab}$ & $0.08 \mathrm{~b}$ & $0.02 \mathrm{~b}$ & $0.06 \mathrm{~b}$ \\
\hline 2008 & $1.46 \mathrm{a}$ & $0.002 \mathrm{~b}$ & $0.012 \mathrm{a}$ & $0.14 \mathrm{~b}$ & $0.50 \mathrm{a}$ & $0.02 \mathrm{~b}$ & $0.02 \mathrm{~b}$ & $0.15 \mathrm{~b}$ & $0.41 \mathrm{a}$ & $0.02 \mathrm{~b}$ & $0.14 \mathrm{a}$ \\
\hline
\end{tabular}

${ }^{\mathrm{z}} \mathrm{TKN}=$ nitrogen in a Kjeldahl digest; TKP $=$ phosphorus in a Kjeldahl digest.

${ }^{y}$ Values in a column followed by the same letter are not significantly different, $P<0.05$, Ryan-Einot-Gabriel-Welsch multiple range test.

Table 6. Effect of year on nutrient content, values in $\mu \mathrm{g} \cdot \mathrm{g}^{-1}$, in soils supporting vegetables.

\begin{tabular}{|c|c|c|c|c|c|c|c|c|c|c|c|c|}
\hline \multirow[b]{2}{*}{ Year } & \multirow[b]{2}{*}{$\mathrm{TKN}^{\mathrm{z}}$} & \multicolumn{2}{|c|}{ Nitrogen } & \multirow[b]{2}{*}{$\mathrm{TKP}^{\mathrm{z}}$} & \multirow[b]{2}{*}{$\mathrm{PO}_{4}$} & \multirow[b]{2}{*}{ Potassium } & \multirow[b]{2}{*}{ Calcium } & \multirow[b]{2}{*}{ Chlorine } & \multirow[b]{2}{*}{ Fluoride } & \multirow[b]{2}{*}{ Magnesium } & \multirow[b]{2}{*}{ Sodium } & \multirow[b]{2}{*}{$\mathrm{SO}_{4}$} \\
\hline & & Nitrate & Nitrite & & & & & & & & & \\
\hline 2005 & $15.9 \mathrm{~b}^{\mathrm{y}}$ & $117.8 \mathrm{a}$ & $6.1 \mathrm{a}$ & $24.4 \mathrm{~b}$ & $6.5 \mathrm{~b}$ & $28.4 \mathrm{~b}$ & $1.14 \mathrm{a}$ & $322.8 \mathrm{~b}$ & $0.00 \mathrm{~b}$ & $0.009 \mathrm{c}$ & $0.72 \mathrm{a}$ & $434.3 \mathrm{a}$ \\
\hline 2006 & $48.9 \mathrm{ab}$ & $70.6 \mathrm{~b}$ & $0.0 \mathrm{c}$ & $29.9 \mathrm{~b}$ & $17.2 \mathrm{a}$ & $41.3 \mathrm{~b}$ & $0.17 \mathrm{c}$ & $494.0 \mathrm{a}$ & $0.56 \mathrm{~b}$ & $0.055 \mathrm{~b}$ & $0.34 \mathrm{~b}$ & $136.0 \mathrm{c}$ \\
\hline 2008 & $79.6 \mathrm{a}$ & $94.2 \mathrm{ab}$ & $4.0 \mathrm{a}$ & $85.9 \mathrm{a}$ & $5.7 \mathrm{~b}$ & $180.0 \mathrm{a}$ & $0.74 \mathrm{~b}$ & $208.5 \mathrm{c}$ & $1.24 \mathrm{a}$ & $0.085 \mathrm{~b}$ & $0.42 \mathrm{~b}$ & $233.4 \mathrm{~b}$ \\
\hline \multicolumn{13}{|c|}{ Cucumber } \\
\hline 2007 & $20.7 \mathrm{bc}$ & $3.9 \mathrm{~b}$ & $1.8 \mathrm{~b}$ & $32.0 \mathrm{~b}$ & $4.1 \mathrm{c}$ & $2.7 \mathrm{c}$ & $0.34 \mathrm{~b}$ & $65.1 \mathrm{c}$ & $1.16 \mathrm{a}$ & $0.16 \mathrm{a}$ & $0.11 \mathrm{c}$ & $31.9 \mathrm{c}$ \\
\hline 2008 & $53.1 \mathrm{a}$ & $10.0 \mathrm{ab}$ & $6.0 \mathrm{a}$ & $88.0 \mathrm{a}$ & $5.9 \mathrm{~b}$ & $180.2 \mathrm{a}$ & $0.78 \mathrm{ab}$ & $176.6 \mathrm{c}$ & $1.07 \mathrm{a}$ & $0.10 \mathrm{a}$ & $0.41 \mathrm{~b}$ & $198.2 \mathrm{~b}$ \\
\hline \multicolumn{13}{|c|}{ Sweet corn } \\
\hline 2005 & $23.4 b^{y}$ & $33.6 \mathrm{~b}$ & $2.8 \mathrm{a}$ & $24.4 \mathrm{~b}$ & $7.2 \mathrm{~b}$ & $28.0 \mathrm{~b}$ & $1.21 \mathrm{a}$ & $236.3 \mathrm{~b}$ & $0.00 \mathrm{c}$ & $0.016 \mathrm{c}$ & $0.74 \mathrm{a}$ & $379.0 \mathrm{a}$ \\
\hline 2006 & $48.0 \mathrm{ab}$ & $52.6 \mathrm{a}$ & $2.6 \mathrm{a}$ & $22.6 \mathrm{~b}$ & $16.7 \mathrm{a}$ & $44.8 \mathrm{~b}$ & $0.17 \mathrm{~b}$ & $482.5 \mathrm{a}$ & $1.04 \mathrm{~b}$ & $0.054 \mathrm{~b}$ & $0.32 \mathrm{~b}$ & $258.4 \mathrm{~b}$ \\
\hline 2007 & $25.0 \mathrm{~b}$ & $6.3 \mathrm{c}$ & $2.4 \mathrm{a}$ & $29.9 \mathrm{~b}$ & $4.6 \mathrm{~b}$ & $3.0 \mathrm{c}$ & $0.34 \mathrm{~b}$ & $80.4 \mathrm{c}$ & $1.93 \mathrm{a}$ & $0.160 \mathrm{a}$ & $0.11 \mathrm{c}$ & $31.8 \mathrm{c}$ \\
\hline
\end{tabular}

${ }^{{ }^{2} \mathrm{TKN}}=$ nitrogen in a Kjeldahl digest; TKP $=$ phosphorus in a Kjeldahl digest.

${ }^{y}$ Values in a column followed by the same letter are not significantly different, $P<0.05$, Ryan-Einot-Gabriel-Welsch multiple range test. 
with conventional fertilizer was $489.1 \mu \mathrm{g} \cdot \mathrm{g}^{-1}$, which was higher than for soil treated with manure, average $259.9 \mu \mathrm{g} \cdot \mathrm{g}^{-1}$. For sweet corn, $\mathrm{Cl}$ level in soil receiving conventional fertilizer was $403.7 \mu \mathrm{g} \cdot \mathrm{g}^{-1}$, which was higher than for soil receiving manure, average $233.7 \mu \mathrm{g} \cdot \mathrm{g}^{-1}$.

Economics - annual costs of production. In 2008, the year used as an example, treatment affected total costs of production and revenue above costs for all crops (Table 7). For bell pepper, the highest costs and highest returns were for the biennial manure application followed by the annual manure application manure and the conventional fertilizer. For cucumber, the highest costs was for the annually applied manure and the highest returns were for the biennial manure application. For sweet corn, the highest costs and returns were associated with the annual application of manure.
Economics-annual and cumulative net return for crops. Treatment affected returns for each crop (Table 8). For bell pepper, plants receiving conventional fertilizer had the highest returns in all but 2008, when both organic treatments had the highest returns. The 4-year cumulative revenue was highest for plants receiving manure with those treated annually having the highest net returns. For cucumber in 2005 and 2007, returns were highest for plants receiving manure biennially. In 2006, the highest returns were for plants receiving manure annually. In 2008, cucumber receiving manure had the highest returns. The 4-year cumulative revenue was highest for plants receiving manure with those treated biennially having the highest net returns. For sweet corn, plants receiving conventional fertilizer had the highest net returns only in 2007. The 4-year cumulative revenue was highest for plants receiving manure; those treated annually had the highest net returns.

\section{Discussion}

In non-vegetable systems, organic production is a viable alternative to conventional production (Chavas et al., 2009). In the Southern Plains in the United States, it was found that profits for vegetables in transition to organic were less than that for conventional production (Russo and Taylor, 2006). When the transition is complete, the question is whether organic production can be profitable and sustainable.

At this location, synthetic fertilizer needs to be added yearly attributable, in part, to the high sand content of soils. Some loss of nutrients can be accounted for by uptake and removal of nutrients associated with removal

Table 7. Annual expenses, \$ U.S. on a hectare basis, for crops produced with manure applied annually or in alternate years or with conventional (conv.) materials and methods, 2008 used as an example.

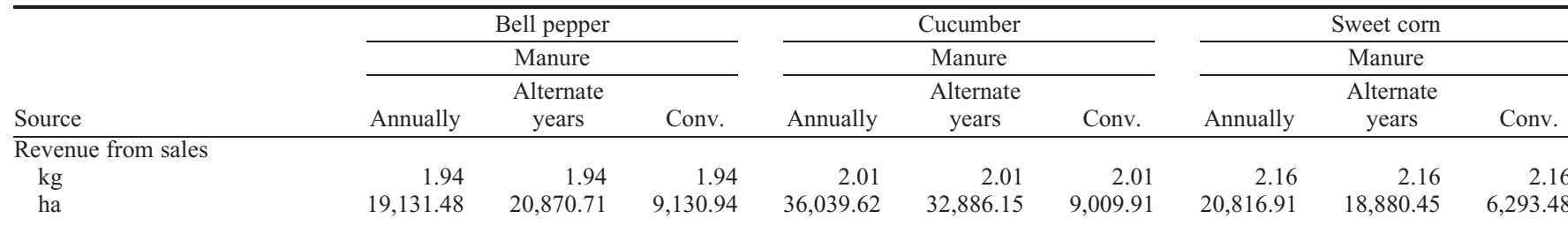

Pre-plant expenses

Manure

Transport (mt)

Apply (mt)

Pesticides

Treflan (herbicide; $1.5 \mathrm{~L}$ )

Dual (herbicide; $1.5 \mathrm{~L}$ )

Synthetic fertilizer 17-17-17 (0.34 mt)

Operations

Disk (2 applications)

Power bed (1 application)

Total

Growing season expenses

Produce (25,160 transplants)

Planting labor

Seeding ${ }^{y}$

Cultivation (2 applications)

Hoeing (1 application)

Irrigation (8 applications)

Entrust (I; 0.2 L)

Dipel (I)

Take Down (I; $1.5 \mathrm{~L})$

Mow (1 application)

Disk (2 applications)

Plant cover crop

Land charge

Total

49.91
62.39

$62.39-\quad-\quad 62.39$

Harvesting and marketing

Operations
Interest $(6 \%)$
Total

Total costs

Revenue above costs

Breakeven to cover costs $(\mathrm{kg})$

- -9.82

- $\quad-$

- $\quad-$

74.13
44.48

230.91

$2,767.57$

$2,012.78$

$\overline{49.42}$

555.98

237.22

-

-

- 24.7

24.71
49.42

42.01

370.65

$6,109.75$

$3,261.72$

288.07

$3,549.79$

$2,767.57$

2,012.78

49.42

555.98

237.22

-

-

24.71

49.42

42.01

370.65

$6,109.75$

$2,767.57$

$2,012.78$

$6,109.75$

3,558.24

293.60

$1,556.73$
240.86
$1,797.59$

$3,851.84$

$9,890.45$

$10,080.00$

$8,269.69$

$9,244.97$

$10,794.82$

$$
\begin{array}{r}
9.82 \\
18.94
\end{array}
$$

214.98

$$
74.13
$$

44.48

362.35

$\overline{49.42}$

555.98

237.22

$-$

-

-

24.71
49.42

42.01

370.65

62.39

-

$-$

\subsection{3}

44.48

230.91

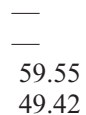

49.42
555.98

237.22

-

-

24.71

49.42

42.01

370.65

$1,329.40$

863.13

$8,697.92$

307.75

$9,005.22$

$10,565.98$

$25,411.78$

- $\quad$ -

-

9.82

18.94

-

214.98

\subsection{3}

44.48

118.61

\subsection{3}

44.48

362.35

\section{-}

59.55
49.42

555.98

237.22

$-$

-

-

24.71
49.42

42.01

370.65

$1,329.40$

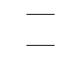

59.55

49.42

555.98

237.22

-

-

24.71

49.42

42.01

370.65

$1,329.40$

$8,480.47$
297.85

$8,778.32$

$\begin{array}{r}115.99 \\ \hline\end{array}$

2,290.47

$10,226.33$

$3,982.21$

$24,851.98$

$5,012.23$
49.41

62.39

-

-

$-$

9.82

18.94

214.98

\subsection{3 \\ 44.48}

230.91

74.13
44.48

44.48
118.61

74.13

44.48

362.35

$z_{-}=$not applicable; transport and cost of manure not accounted for in 2008 alternate application year plots.

${ }^{\mathrm{y}}$ Purchase and seed sowing costs. 
Table 8. Total revenue, total costs, and net revenue for vegetables supplied manure on an annual or biennial basis or produced with conventional production in 4 years.

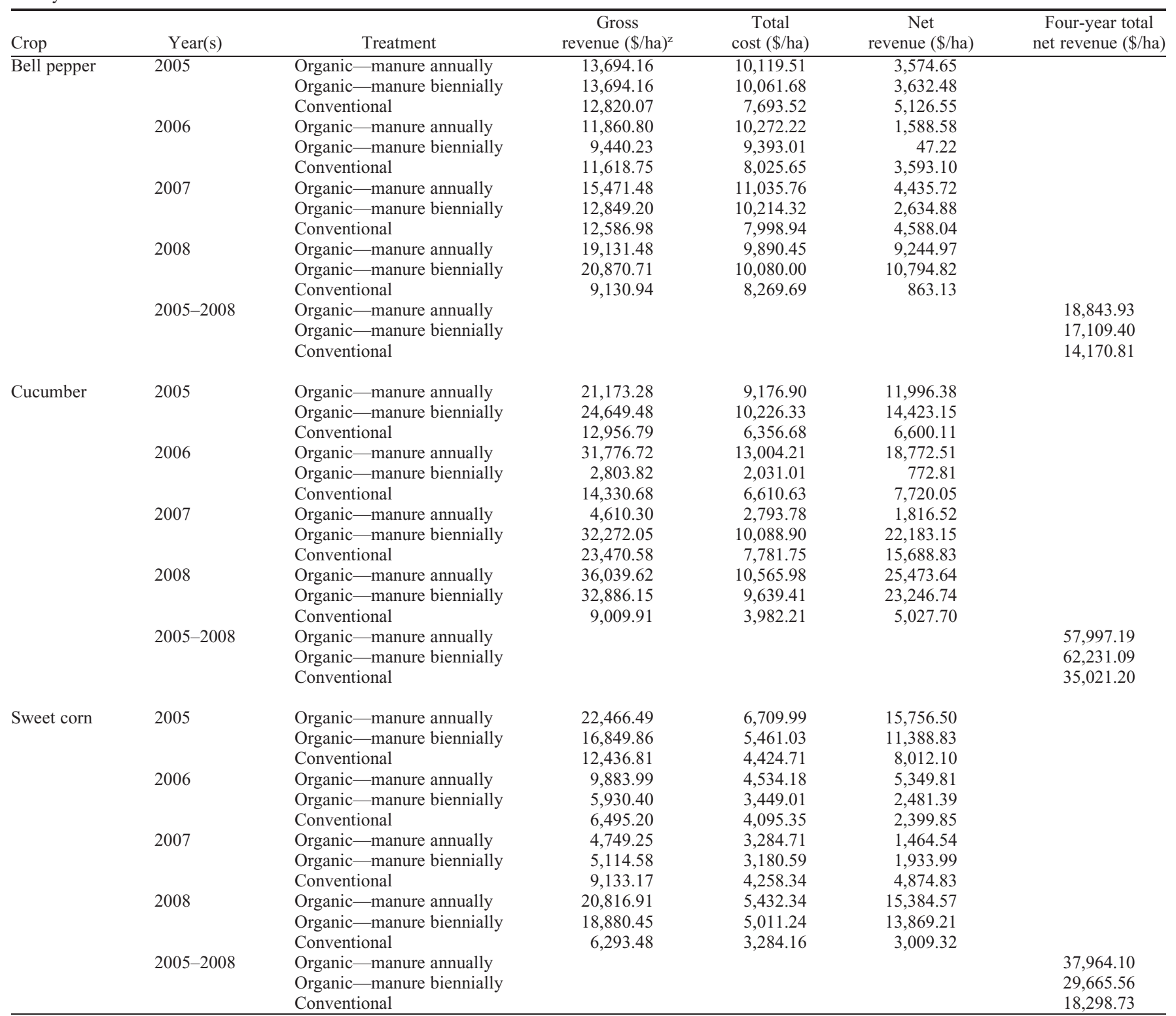

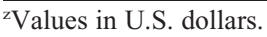

of edible portions of the plant from the field, but most is lost as a result of leaching or volatilization. Synthetic fertilizers are soluble and immediately available to plants; organic fertilizers change the conditions of the soil (Simpson, 1986; Taylor and Zenz, 1999). Nutrients from manure are released over time. As a result, there may be a repository of undegraded manure remaining, which could carry over through an additional growing season. The pattern of changes in yield, or nutrient content of edible portions, did not appear to be solely the result of annual or biennial application of manure. More needs to be determined concerning manure management in relation to soil condition. Application of manure has benefits other than delivery of nutrients. Soil condition is affected because organic material is added with the manure and soil microbial populations are affected. There were responses resulting from year, and this may be attributable to variation in tem- perature and rainfall. Distribution of rain can affect nutrient leaching in soil and pollen transfer in crops. Temperature can affect pollen viability.

There is a concern regarding accumulation of phosphorus in the soil resulting from annual application of manure (Roberts et al., 2004). The $P$ in the soil was higher at the end of the experiment than at the beginning. The levels were stable through 2007 with the increase noted in 2008. An interaction to determine if frequency of manure application affected soil P level did not exist. It is not clear if the biennial application of manure affected soil $\mathrm{P}$ level and needs further examination.

Taylor et al. (2006) reported that production costs for vegetables using organic methods are generally higher than for conventional methods. Profit from organic production could be reduced if a premium is not provided to organic products. Even if a pre- mium exists, there is no guarantee it will continue over time if vegetables under organic production acquires a similar acceptance to those from conventional production. During the period of this study, there was no premium provided to organically produced crops at the Dallas terminal market. Even if premiums are not afforded, the results indicate that organic production of bell pepper, cucumber, and sweet corn was competitive. The gross, net, and potential revenues from organic production could be underestimated. In most locations in the United States where value of organic vegetables is differentiated, organic vegetables generally sell for more than conventionally produced vegetables (Brust et al., 2003). This marketing premium can be as much as $65 \%$ as demonstrated for vegetables at the Boston Wholesale Terminal Market in 2008 (U.S. Department of Agriculture, Economic Research Service, 2009). Cost impacts production, delivery, and application of synthetic 
materials. Some of these same costs will be applied to organic production, but if the material for use in organic fertilizers and soil amendments does not begin with oil, and is locally produced with minimal shipping costs, the gap between costs of organic and conventional production may be closed.

Under purely economic analysis, it appeared, for the transition period that conventional methods should be chosen for vegetable producers (Russo and Taylor, 2006). However, factors affecting acceptance of use of organic methods can transcend economic justification. Once the transition period was completed, organic production of these same vegetables was as good as, or better than, conventionally grown vegetables. Nutrient content of all crops was virtually indistinguishable between organically and conventionally grown crops. For crops receiving manure, the response to treatment appeared to be more related to yearly fluctuations of the production environment than application of manure. Over the 4-year period, total revenue for bell pepper and sweet corn treated biennially with manure was $\approx 90 \%$ and $78 \%$, respectively, of those treated annually. For cucumber net revenue was about $7 \%$ higher for plants treated with manure biennially. The cost of inputs is a necessary consideration in all production systems. Manure may have to be applied annually so biological interactions begun resulting from application can be sustained. Annual use of manure appears to be necessary for most of the vegetable crops tested.

\section{Literature Cited}

Arden-Clarke, C. and R.D. Hodges. 1988. The environmental effects of conventional and organic/ biological farming systems. II. Soil ecology, soil fertility and nutrient cycles. Biol. Agr. Hort. 5:223-287.

Asami, D.K., Y.-J. Hong, D.M. Barrett, and A.E. Mitchell. 2003. Comparison of the total phenolic and ascorbic acid content of freeze-dried and airdried Marionberry, strawberry, and corn using conventional, organic and sustainable agricultural practices. J. Agr. Food Chem. 51:1237-1241.

Brust, G., D.S. Engel, and E.T. Maynard. 2003. Organic vegetable production. Purdue University Extension Publication ID-316. Purdue University, West Lafayette, IN.

Chavas, J.-P., J.L. Posner, and J.L. Hedtcke. 2009. Organic and conventional production systems in the Wisconsin integrated cropping systems trial: II. Economic and risk analysis 19932006. Agron. J. 101:288-295.

Dabbert, S. and P. Madden. 1986. The transition to organic agriculture: A multi-year simulation model of a Pennsylvania farm. Amer. J. Altern. Agr. 1:99-107.

Dimitri, C. and C. Greene. 2002. Recent growth patterns in the U.S. organic foods market. U.S. Department of Agriculture Economic Research service, Market and Trade Economics Division and Resource Economic Division. Agriculture Information Bulletin Number 777. <http://www. ers.usda.gov/publications/aib777/aib777.pdf>.

Johnson, G. 1985. How to get a good soil sample. OSU Extension Facts, No. 2207. Oklahoma State University, Stillwater, OK.

Lalande, R., B. Gagnon, R.A. Chapman, and G.M. Barnett. 2005. Soil microbial populations, activity, and community structure in continuous corn or forage systems under organic or inorganic fertilization in eastern Canada. Can. J. Soil Sci. 85:27-38.

McLaurin, W. and W. Reeves. 2000. How to convert an inorganic fertilizer recommendation to an organic one. The University of Georgia, Cooperative Extension service circular 853 .

Merrill, M.C. 1983. Eco-agriculture: A review of its history and philosophy. Biol. Agr. Hort. 1:181-210.

Motes, J. and W. Roberts. 1994. Fertilizing commercial vegetables. Oklahoma State University, Agricultural Experiment Station. OSU Extension Facts. F-6000.

Nardi, S., F. Morari, A. Berti, M. Tosoni, and L. Giardini. 2004. Soil organic matter properties after 40 years of different use of organic and mineral fertilizers. Eur. J. Agron. 21:357-367.

Organic Trade Association. 2007. Executive summary. Organic Trade Association's 2007 manufacturer survey. $<\mathrm{http} / /$ www.ota.com/pics/ documents/2007ExecutiveSummary $>$.

Ozores-Hampton, M. and D.R.A. Peach. 2002. Biosolids in vegetable production systems. HortTechnology 12:336-340.

Roberts, W., J. Edelson, J. Shrefler, and M. Taylor 2004. Long-term soil changes as affected by poultry litter applications. HortScience 39:655 (Abstract).

Russo, V.M. 2005. Organic vegetable transplant production. HortScience 40:623-628.

Russo, V.M. and P. Perkins-Veazie. 2010. Yield and nutrient content of bell pepper pods from plants developed from seedlings inoculated, or not, with microorganisms. HortScience 45:352-358.

Russo, V.M. and M. Taylor. 2006. Soil amendments in transition to organic vegetable production with comparison to conventional methods: Yields and economics. HortScience 41:15761583.
Sellen, D., J.H. Tolman, D.G.R. McLeod, A. Weersink, and E.K. Yiridoe. 1995. A comparison of financial returns during early transition from conventional to organic vegetable production. J. Veg. Crop Prod. 1:11-39.

Simpson, K. 1986. Fertilizers and manures. Longman, New York, NY.

Smolik, J.D. and T.L. Dobbs. 1991. Crop yields and economic returns accompanying the transition to alternative farming systems. J. Prod. Agr. 4:153-161.

Stanhill, G. 1990. The comparative productivity of organic agriculture. Agr. Ecosyst. Environ. 30: $1-26$.

Taylor, M.J., W. Roberts, J. Edelson, J. Shrefler, V. Russo, B. Bruton, S. Pair, A. Davis, and C. Webber. 2006. Economic evaluation of four (4) crop organic vegetable rotation. Proc. OklahomaArkansas Horticult. Industries Show 25:113115.

Taylor, N. and L. Zenz (eds.). 1999. Organic resource manual. Washington State Department of Agriculture. SARE Project EW-96.006, Publ. 030, Washington State University, Olympia, WA.

U.S. Department of Agriculture, Agricultural Marketing Service. 1958. United States standards for grades of cucumbers. Washington, DC. $<$ http://www.ams.usda.gov/AMSv1.0/getfile? $\mathrm{dDocName}=$ STELPRDC5050262 $>$.

U.S. Department of Agriculture, Agricultural Marketing Service. 1989. United States standards for grades of sweet peppers. Washington, DC. $<$ http://www.ams.usda.gov/standards/ PEPERSWT1.pdf $>$.

U.S. Department of Agriculture, Agricultural Marketing Service. 1992. United States standards for grades of sweet corn. Washington, DC $<$ http://www.ams.usda.gov/standards/cornswt. pdf $>$.

U.S. Department of Agriculture, Agricultural Marketing Service. 2004. 7 CFR Part 205. National Organic Program. $<$ http://www.usda.gov/NOP $>$.

U.S. Department of Agriculture, Agricultural Marketing Service. 2005-2008. Dallas wholesale fruit and vegetable report. <http://www.ams. usda.gov/marketnews.htm>.

U.S. Department of Agriculture, Economic Research Service. 2009. Organic prices for commodities. $<$ http://www.ers.usda.gov/data/OrganicPrices $>$.

Verma, S., S.K. Subehia, and S.P. Sharma. 2005. Phosphorus fractions in an acid soil continuously fertilized with mineral and organic fertilizers. Biol. Fertil. Soils 41:295-300.

Woese, K., D. Lange, C. Boess, and K.W. Bögl. 1997. A comparison of organically and conventionally grown foods-results of a review of the relevant literature. J. Sci. Food Agr. 74: 281-293. 